\title{
Stimulation of DNA synthesis in rat and mouse liver by various tumor promoters
}

\author{
Büsser, Marie-Therese ; Lutz, Werner K
}

\begin{abstract}
In order to investigate whether the stimulation of liver DNA synthesis might be used to detect one class of hepatic tumor promoters, the incorporation of orally administered radio-labelled thymidine into liver DNA was determined in rats and mice $24 \mathrm{~h}$ after a single oral gavage of test compounds at various dose levels. Three DNA-binding hepatocarcinogens, aflatoxin B1,- benzidine and carbon tetrachloride, did not stimulate but rather inhibited DNA synthesis (not for CCl4 Four hepatic tumor promoters, clofibrate, DDT, phenobarbital and thioacetainide, gave rise to a stimulation in a dose-dependent manner. Single oral doses between 0.02 and $0.3 \mathrm{mmol} / \mathrm{kg}$ were required to double the level of thymidine incorporation into liver DNA (= doubling dose, DD). Differences between species or sex as obsserved in long-term carcinogenicity studies were reflected by a different stimulation of liver DNA synthesis. In agreement with the bioassay data, aldrin was positive only in male mice $(\mathrm{DD}=0.007 \mathrm{mmol} / \mathrm{kg}$ ) but not in male rats or female mice. 2,3,7,8-TCDD was positive in male mice ( $\mathrm{DD}=10-6 \mathrm{mmol} / \mathrm{kg}$ ) and in female rats (DD $=2 \times 10-6 \mathrm{mmol} / \mathrm{kg}$ ) but not in male rats. The assay was also able to distinguish between structural isomers with different carcinogenicities. [alpha]Hexchlorocyclohexane stimulated liver DNA synthesis with a doubling dose of about $0.2 \mathrm{mmol} / \mathrm{kg}$ in male rats whereas the [gamma]-isomer was ineffective even at $1 \mathrm{mmol} / \mathrm{kg}$. So far, only one result was inconsistent with carcinogenicity bioassay data. The different carcinogenicity of di(2-ethylhexyl)adipate (negative in rats) and di(2-ethylhexyl)phthalate (positive) was not detectable. Both plasticizers were positive in this short-term system with DD's of $0.7 \mathrm{mmol} / \mathrm{kg}$ for DEHA and $0.5 \mathrm{mmol} / \mathrm{kg}$ for DEHP. The proposed assay is discussed as an attempt to devise short-term assays for carcinogens not detected by the routine genotoxicity test systems
\end{abstract}

DOI: https://doi.org/10.1093/carcin/8.10.1433

Posted at the Zurich Open Repository and Archive, University of Zurich

ZORA URL: https://doi.org/10.5167/uzh-154090

Journal Article

Published Version

Originally published at:

Büsser, Marie-Therese; Lutz, Werner K (1987). Stimulation of DNA synthesis in rat and mouse liver by various tumor promoters. Carcinogenesis, 8(10):1433-1437.

DOI: https://doi.org/10.1093/carcin/8.10.1433 


\section{Stimulation of DNA synthesis in rat and mouse liver by various tumor promoters}

\author{
Marie-Therese Büsser and Werner K.Lutz ${ }^{1}$ \\ Institute of Toxicology, Swiss Federal Institute of Technology and University \\ of Zurich, CH-8603 Schwerzenbach, Switzerland \\ ${ }^{1}$ To whom reprint requests should be sent
}

In order to investigate whether the stimulation of liver DNA synthesis might be used to detect one class of hepatic tumor promoters, the incorporation of orally administered radiolabelled thymidine into liver DNA was determined in rats and mice $24 \mathrm{~h}$ after a single oral gavage of test compounds at various dose levels. Three DNA-binding hepatocarcinogens, aflatoxin $B_{1}$; benzidine and carbon tetrachloride, did not stimulate but rather inhibited DNA synthesis (not for $\mathrm{CCl}_{4}$ ). Four hepatic tumor promoters, clofibrate, DDT, phenobarbital and thioacetamide, gave rise to a stimulation in a dosedependent manner. Single oral doses between 0.02 and $0.3 \mathrm{mmol} / \mathrm{kg}$ were required to double the level of thymidine incorporation into liver DNA (= doubling dose, DD). Differences between species or sex as obsprved in long-term carcinogenicity studies were reflected by a different stimulation of liver DNA synthesis. In agreement with the bioassay data, aldrin was positive only in male mice (DD $=0.007 \mathrm{mmol} / \mathrm{kg}$ ) but not in male rats or female mice. 2,3,7,8-TCDD was positive in male mice (DD $=10^{-6} \mathrm{mmol} / \mathrm{kg}$ ) and in female rats $\left(D D=2 \times 10^{-6} \mathrm{mmol} / \mathrm{kg}\right.$ ) but not in male rats. The assay was also able to distinguish between structural isomers with different carcinogenicities. [alpha]Hexachlorocyclohexane stimulated liver DNA synthesis with a doubling dose of about $0.2 \mathrm{mmol} / \mathrm{kg}$ in male rats whereas the [gamma]isomer was ineffective even at $1 \mathrm{mmol} / \mathrm{kg}$. So far, only one result was inconsistent with carcinogenicity bioassay data. The different carcinogenicity of di(2-ethylhexyl)adipate (negative in rats) and di(2-ethylhexyl)phthalate (positive) was not detectable. Both plasticizers were positive in this short-term system with DD's of $0.7 \mathrm{mmol} / \mathrm{kg}$ for DEHA and $0.5 \mathrm{mmol} / \mathrm{kg}$ for DEHP. The proposed assay is discussed as an attempt to devise short-term assays for carcinogens not detected by the routine genotoxicity test systems.

\section{Introduction}

A number of short-term tests exist for the assessment of the carcinogenic potential of chemicals. Most of these detect only carcinogens which interact with nucleic acids (1), or potentially induce DNA repair synthesis (2) or mutations in bacteria or mammalian cells $(3,4)$. An increasing number of compounds are being found to induce tumors in a long-term bioassay although they generally produce negative results in the above genotoxicity tests.

\footnotetext{
*Abbreviations: CLF, clofibrate; PB, phenobarbital; DD, doubling dose; $\mathrm{AFB}_{1}$, aflatoxin $\mathrm{B}_{1}$; $\mathrm{BZD}$, benzidine; [alpha] $\mathrm{HCH}$, [alpha]hexachlorocyclohexane; [gamma]HCH, [gamma]hexachlorocyclohexane; ALD, aldrin; DDT, 1,1,1trichloro-2,2-bis(p-chlorophenyl)ethane; DEHP, di(2-ethylhexyl)phthalate; TAA, thioacetamide; DEHA, di(2-ethylhexyl)adipate; TCDD, 2,3,7,8-tetrachlorodibenzo-p-dioxin; $\left[{ }^{14} \mathrm{C}\right] \mathrm{TdR}$, [methyl- $\left.{ }^{14} \mathrm{C}\right]$ thymidine; $\left[{ }^{3} \mathrm{H}\right] \mathrm{TdR}$, [methyl- $\left.{ }^{3} \mathrm{H}\right]-$ thymidine; TdRII, thymidine incorporation index; SF, stimulation factor.
}

They are often active as tumor promoters in two-stage experiments and exhibit biological activities as hormones (e.g. ethinylestradiol), peroxisome proliferators [e.g. clofibrate $\left(\mathrm{CLF}^{*}\right)$ ] or enzyme inducers [e.g. phenobarbital (PB)]. A correlation of these activities with the carcinogenicity of these compounds might be empirical but it could form the basis for short-term assays. At the present time only the initiationpromotion assay is employed routinely in the liver $(5-7)$. The test compounds are examined for their ability to promote tumor or foci formation after initiation with a known genotoxic agent. In the search for a potentially common biological activity of some tumor promoters, our decision fell on the stimulation of DNA synthesis. Although not a sufficient condition $(8,9)$, cell division seems to be a prerequisite in a number of stages in the process of carcinogenesis. Firstly, the replication of damaged DNA is a necessary event for a successful initiation (10-13). Secondly, the mitotic activity plays an important role during the period of tumor promotion and progression (14).

In this report we investigated the ability of different hepatocarcinogens to stimulate DNA synthesis in the liver of rats and mice. The experimental system elaborated by Schulte-Hermann and co-workers (15) was applied. Radiolabelled thymidine incorporation was measured in the peak phase of the diurnal cycle of liver DNA synthesis, $24 \mathrm{~h}$ after administration of the test compounds at various dose levels. The dose which produced a doubling of the control level DNA synthesis was named the doubling dose (DD) and was used for quantitative comparisons. In a first set of experiments, DNA-binding carcinogens were compared with classical hepatic tumor promoters to check whether it is possible to distinguish between the two classes. The system was tested further by using carcinogens with different potencies in different species (rats versus mice) or sex. Non-carcinogenic structural isomers of hepatocarcinogens were also investigated.

\section{Materials and methods}

Animals

Rats were from Ivanovas, Kisslegg, FRG (Iva:SIV-50 SD), from the University Hospital Zürich, Switzerland (Osbome-Mendel) or from Charles River, Sulzfeld, FRG [Crl:CD(SD)BR or CDF(F-344)/CrlBR]. Mice were from Charles River, Sulzfeld, FRG (B6C3F 1 CrlBR).

The animals were kept in Marcolone cages, the rats in pairs, the mice in groups of four. The illumination time was from 9 a.m. to 9 p.m. Food pellets (Haltungsdiät Nr. 343, Klingental Mühle AG, Kaiseraugst, Switzerland) in unlimited quantity were available only between 9 p.m. and 2 a.m. For certain control experiments, food availability was extended to 15 h (9 p.m. to 12 a.m.). Drinking water was available at all times. The animals were kept untreated for an acclimatization period of at least 2 weeks, whereafter weight gain was as high as without restricted diet. Treatment groups usually consisted of four animals, in some cases there were only two animals per group (aflatoxin $B_{1}\left[A F B_{1}\right]$, benzidine [BZD], $\mathrm{CCL}_{4}, \mathrm{CLF}, \mathrm{PB}$, [alpha]hexachlorocyclohexane ([alpha]HCH), [gamma]hexachlorocyclohexane $\{$ gamma]HCH$\}$ ). The animals' weight was recorded twice a week.

\section{Chemicals}

The following test compounds were used: AFB, (Senn AG, Dielsdorf, Switzerland), aldrin (ALD) (Riedel De Haen AG, Seelze, FRG), BZD (Fluka AG, Buchs, Switzerland), $\mathrm{CCl}_{4}$ (Merck, Darmstadt, FRG), CLF, 1,1,1-trichloro-2,2-bis(p-chlorophenyl)ethane (DDT), di(2-ethylhexyl)phthalate (DEHP) 
and thioacetamide (TAA) (all from Fluka AG, Buchs, Switzerland), di(2-ethylhexyl)adipate (DEHA) (Merck, Darmstadt, FRG), [alpha]HCH and [gamma]HCH (Celamerck GmbH Co., Ingelheim/Rhein, FRG), PB (Siegfried AG, Zofingen, Switzerland), 2,3,7,8-tetrachlorodibenzo-p-dioxin (TCDD) (Givaudan AG, Dübendorf, Switzerland).

Application solutions were made up in corn oil (ALD, CLF, CCl, DEHA, DEHP, [alpha]HCH, [gamma]HCH, DDT, TCDD), in ethanol (AFB, BZD) or in $0.9 \%$ aqueous $\mathrm{NaCl}$ (PB, TAA).

Radiolabelled thymidine and methanol were from The Radiochemical Centre, Amersham, UK.

\section{Treatments}

Test compounds were administered p.o. at 8 a.m. at the dose levels indicated in the tables. For most carcinogens which do not bind to DNA, the highest dose level chosen approximated the $T D_{50}$, i.e. the daily dose which would induce a tumor in $50 \%$ of the animals when applied daily over their lifetime. Intermediate and low doses, if applicable, were one tenth and one hundredth thereof. Groups of control animals received the vehicle only. The highest dose level of [gamma]$\mathrm{HCH}$ was above the $\mathrm{LD}_{50}$ range. The animals did not show any sign of toxicity, however, under the conditions of this assay and the liver DNA synthesis after $24 \mathrm{~h}$ was still at $80 \%$ of control.

Twenty-four hours later all animals were given radioactive thymidine p.o. Rats received $2-5 \mu \mathrm{Ci} / \mathrm{kg}$ [methyl ${ }^{14} \mathrm{C}$ ]thymidine $\left(\left[{ }^{14} \mathrm{C}\right] \mathrm{TdR}\right)(54 \mathrm{mCi} / \mathrm{mmol})$ or $6-15 \mu \mathrm{Ci} / \mathrm{kg}$ [methyl $\left.{ }^{3} \mathrm{H}\right]$ thymidine $\left(\left[{ }^{3} \mathrm{H}\right] \mathrm{TdR}\right)(40 \mathrm{Ci} / \mathrm{mmol})$, mice received $10 \mu \mathrm{Ci} / \mathrm{kg}\left[{ }^{14} \mathrm{C}\right] \mathrm{TdR}(54 \mathrm{mCi} / \mathrm{mmol})$ in $0.9 \%$ aqueous $\mathrm{NaCl}$. For certain control experiments the animals were administered $140 \mu \mathrm{Ci} / \mathrm{kg}\left[{ }^{14} \mathrm{C}\right]$ methanol $(59 \mathrm{mCi} / \mathrm{mmol})$, or, for autoradiographic investigations, $1 \mathrm{mCi} / \mathrm{kg}\left[{ }^{3} \mathrm{H}\right] \mathrm{TdR}$ $(5 \mathrm{Ci} / \mathrm{mmol})$. When using ${ }^{14} \mathrm{C}-\mathrm{TdR}$, one animal of each dose group and one control was placed in a glass metabolism cage, where the carbon dioxide expired was trapped with ethanolamine/methanol 1:4. Aliquots of this solution were counted for ${ }^{14} \mathrm{C}$ radioactivity $3 \mathrm{~h}$ after the TdR administration. Four hours after thymidine administration the animals were killed by an ether overdose.

DNA isolation

The livers were excised and minced and DNA was isolated by an abbreviated standard procedure (16), essentially by phenol extraction and hydroxylapatite adsorption chromatography.

An aliquot of the DNA was counted for radioactivity after addition of $10 \mathrm{ml}$ Insta-Gel (Packard Instruments, Downers Grove, USA) by liquid scintillation counting in a Packard model $460 \mathrm{CD}$ equipped with and calibrated for the determination of ${ }^{3} \mathrm{H} /{ }^{14} \mathrm{C}$-double-labelled samples. The amount of DNA was assessed on the basis of the u.v. absorbance at $260 \mathrm{~nm}$, taking an extinction value of 20 for a solution of $1 \mathrm{mg} / \mathrm{ml}$.

\section{Liver histology and autoradiography}

Fresh liver tissue of two animals in each group treated with DDT, TAA, ALD, TCDD, DEHA and DEHP was fixed in formalin, embedded in paraffin, cut into sections of $5 \mu \mathrm{m}$ thickness and stained with hematoxylin and eosin.

For autoradiography, the $5 \mu \mathrm{m}$ sections were dipped in photographic emulsion (Ilford K2-Gel, Ilford Ltd, Basildon, Essex, UK). Exposure time at $4^{\circ} \mathrm{C}$ was 2-3 weeks.

\section{Calculations and statistics}

The specific activity of the DNA (expressed in d.p.m./mg) was divided by the dose of thymidine radioactivity administered (expressed in $\mathrm{d} . \mathrm{p.m} . / \mathrm{kg}$ ) and this value was multiplied by $3.09 \times 10^{8}$ in order to convert the data to the molar units of a thymidine incorporation index. TdRII $=(\mu \mathrm{mol} T \mathrm{TR}$ incorporated per mol DNA-nucleotide)/(mmol TdR administered per $\mathrm{kg}$ body $w t)$.

The multiplication factor between the mean TdRII of the untreated control group and the treated groups was called the stimulation factor (SF). The $t$-test was used for the assessment of statistical significance $(P)$. The dose required for each compound to induce a doubling of the liver DNA synthesis, the DD, has an SF of 2.

The symbols,-+ to +++++ , indicating an approximate carcinogenic potency in the tables, were assigned according to $\mathrm{TD}_{50}$ values (17) [expressed in $\mathrm{mmol} / \mathrm{kg}$ (days)]: - , no significant increase under the bioassay conditions used; ,$+ 10>\mathrm{TD}_{50}>1 ;++, 1>\mathrm{TD}_{50}>0.1 ;+++, 0.1>\mathrm{TD}_{50}>0.01$; ,$++++ 0.01>\mathrm{TD}_{50}>0.0001 ;+++++, 0.0001>\mathrm{TD}_{50}>0.000001$. For the carcinogenic potency ranking used in our quantitative evaluation the chemicals are therefore specified as carcinogens rather than as promoters.

\section{Results}

\section{DNA-binding carcinogens versus tumor promoters}

The first question to answer was whether the proposed system was specific for carcinogens acting without covalent DNA binding.

Table I shows that the three DNA-binding carcinogens AFB (18a), BZD $(18 \mathrm{a}, \mathrm{e})$ and $\mathrm{CCl}_{4}(18 \mathrm{a}, \mathrm{c})$ did not stimulate cell divi-
Table I. Correlation of carcinogenic potency with stimulation of liver DNA synthesis; DNA-binding agents

\begin{tabular}{|c|c|c|c|c|c|}
\hline Compound & $\begin{array}{l}\text { Species/sex } \\
\text { strain }\end{array}$ & $\begin{array}{l}\text { Carcino- } \\
\text { genic } \\
\text { potency }\end{array}$ & $\begin{array}{l}\text { Dose } \\
(\mathrm{mmol} / \mathrm{kg})\end{array}$ & $\begin{array}{l}\text { Stimulation } \\
\text { factor }\end{array}$ & $\begin{array}{l}\text { Doubling } \\
\text { dose } \\
(\mathrm{mmol} / \mathrm{kg})\end{array}$ \\
\hline Aflatoxin $B_{l}$ & $\begin{array}{l}\text { Rat/male } \\
\text { SIV-50 SD }\end{array}$ & +++++ & $\begin{array}{l}0.001 \\
0.0001 \\
0.00001\end{array}$ & $\begin{array}{l}0.4^{a *} \\
0.3^{a * *} \\
0.2^{a * *}\end{array}$ & $\begin{array}{l}\text { Inhibition } \\
\text { Inhibition } \\
\text { Inhibition }\end{array}$ \\
\hline Benzidine & $\begin{array}{l}\text { Rat/male } \\
\text { SIV-50 SD }\end{array}$ & +++ & $\begin{array}{l}1.0 \\
0.1 \\
0.01\end{array}$ & $\begin{array}{l}0.5^{a *} \\
0.3^{a * *} \\
0.8^{a}\end{array}$ & $\begin{array}{l}\text { Inhibition } \\
\text { Inhibition }\end{array}$ \\
\hline $\mathrm{CCl}_{4}$ & $\begin{array}{l}\text { Rat/male } \\
\text { SIV-50 SD }\end{array}$ & + & $\begin{array}{l}1.0 \\
0.1 \\
0.01\end{array}$ & $\begin{array}{l}1.0^{a} \\
1.2^{a} \\
1.5^{a}\end{array}$ & \\
\hline
\end{tabular}

The stimulation factor indicates the ratio of the thymidine incorporation in treated animals over the value in the related control group.

${ }^{*} 0.1 \geq P>0.05 ;{ }^{* *} P<0.05$ ( $t$-test).

${ }^{a}$ The related control group (Table VI).

Table II. Correlation of carcinogenic potency with stimulation of liver DNA synthesis; hepatic tumor promoters which do not bind to DNA

\begin{tabular}{llllll}
\hline Compound & $\begin{array}{l}\text { Species/sex } \\
\text { strain }\end{array}$ & $\begin{array}{l}\text { Carcıno- } \\
\text { genic } \\
\text { potency }\end{array}$ & $\begin{array}{l}\text { Dose } \\
(\mathrm{mmol} / \mathrm{kg})\end{array}$ & $\begin{array}{l}\text { Stimulation } \\
\text { factor }\end{array}$ & $\begin{array}{l}\text { Doubling } \\
\text { dose } \\
(\mathrm{mmol} / \mathrm{kg})\end{array}$ \\
\hline Clofibrate & Rat/male & ++ & 1.0 & $3.4^{a * *}$ & 0.1 \\
& SIV-50 SD & & 0.1 & $\begin{array}{l}2.2^{a * *} \\
0.8^{a}\end{array}$ & \\
DDT & Rat/male & ++ & 0.05 & $2.8^{c_{*}}$ & 0.02 \\
& $\mathrm{CD}(\mathrm{SD})$ & & 0.005 & $1.4^{d}$ & \\
Phenobarbital & Rat/male & ++ & 0.1 & $2.5^{a * *}$ & 0.1 \\
& SIV-50 SD & & 0.01 & $1.1^{a}$ & \\
Thioacetamide & Rat/male & +++ & 0.27 & $2.0^{g *}$ & 0.3 \\
& $\mathrm{CD}(\mathrm{SD})$ & & 0.027 & $1.6^{g}$ & \\
\hline
\end{tabular}

${ }^{*} 0.1 \geq P>0.05 ;{ }^{* *} P<0.05$ ( $t$-test).

$a, c, d, 8$ The related control group (Table VI).

sion. $\mathrm{AFB}_{1}$ and $\mathrm{BZD}$ actually inhibited DNA synthesis. This has been observed frequently with genotoxic agents as a first cellular response. On the other hand, four classical hepatocarcinogens which do not bind to DNA and which are negative in most tests of mutagenicity, CLF (18d), DDT (19), PB (19) and TAA (20), gave rise to a 2.0-3.4-fold stimulation of DNA synthesis at the highest dose level (Table II). The approximate interpolated DD for these agents ranged between 0.02 and $0.3 \mathrm{mmol} / \mathrm{kg}$ with DDT being the most potent.

Species and sex differences

ALD induces liver tumors in male mice, but not in female mice or in rats (21b). The assay was able to reproduce this difference. DNA synthesis was stimulated only in male mice (Table III). Here, ALD was a potent stimulator with a doubling dose of $0.007 \mathrm{mmol} / \mathrm{kg}$.

TCDD is a carcinogen for male mice and female rats, but not for male rats (22a). Again, TCDD was negative in male rat liver, but was a very potent stimulator of DNA synthesis in male mice with a DD of $10^{-6} \mathrm{mmol} / \mathrm{kg}$ and in female rats with a DD of $2 \times 10^{-6} \mathrm{mmol} / \mathrm{kg}$ (Table III). TCDD, measured in mice, was the most potent stimulator of all compounds tested. TCDD had been tested before in rats and was found to be negative for male and female rats (23). The discrepancy could be explained by the 
Table III. Correlation of carcinogenic potency with stimulation of liver DNA synthesis; compounds with different carcinogenic potency in different species and sexes

\begin{tabular}{llllll}
\hline Compound & $\begin{array}{l}\text { Species/sex } \\
\text { strain }\end{array}$ & $\begin{array}{l}\text { Carcino- } \\
\text { genic } \\
\text { potency }\end{array}$ & $\begin{array}{l}\text { Dose } \\
(\mathrm{mmol} / \mathrm{kg})\end{array}$ & $\begin{array}{l}\text { Stimulation } \\
\text { factor }\end{array}$ & $\begin{array}{l}\text { Doubling } \\
\text { dose } \\
(\mathrm{mmol} / \mathrm{kg})\end{array}$ \\
\hline Aldrin & $\begin{array}{l}\mathrm{Rat} / \mathrm{male} \\
\mathrm{OM}\end{array}$ & - & 0.016 & $1.3^{b}$ & \\
& $\begin{array}{l}\text { Mouse/male } \\
\mathrm{B} 6 \mathrm{C} 3 \mathrm{~F}_{1}\end{array}$ & +++ & 0.011 & $3.1^{\prime *}$ & 0.007 \\
& $\begin{array}{l}\text { Mouse/female } \\
\mathrm{B} 6 \mathrm{C} 3 \mathrm{~F}_{1}\end{array}$ & - & 0.008 & $1.2^{\prime}$ & \\
$\mathrm{TCDD}$ & $\begin{array}{l}\text { Rat/male } \\
\mathrm{CD}(\mathrm{SD})\end{array}$ & - & 0.00003 & $1.1^{f}$ & \\
& & 0.000003 & $1.5^{f}$ & \\
& $\begin{array}{l}\text { Rat/female } \\
\mathrm{CD}(\mathrm{SD})\end{array}$ & +++++0.0000008 & $1.5^{h *}$ & 0.000002 \\
& $\begin{array}{l}\text { Mouse/male } \\
\mathrm{B} 6 \mathrm{C} 3 \mathrm{~F}_{1}\end{array}$ & +++++ & 0.0000008 & $1.7^{k * *}$ & 0.000001 \\
\hline
\end{tabular}

${ }^{*} 0.1 \geq P>0.05 ; * * P<0.05$ ( $t$-test).

$b, f, h, l, k$ The related control group (Table VI).

Table IV. Correlation of carcinogenic potency with stimulation of liver DNA synthesis; structural isomers with different carcinogenicity

\begin{tabular}{llllll}
\hline Compound & $\begin{array}{l}\text { Species/sex } \\
\text { strain }\end{array}$ & $\begin{array}{l}\text { Carcino- } \\
\text { genic } \\
\text { potency }\end{array}$ & $\begin{array}{l}\text { Dose } \\
\text { (mmol/kg) }\end{array}$ & $\begin{array}{l}\text { Stimulation } \\
\text { factor }\end{array}$ & $\begin{array}{l}\text { Doubling } \\
\text { dose } \\
\text { (mmol/kg) }\end{array}$ \\
\hline [alpha]HCH & Rat/male & ++ & 1.0 & $3.4^{a * *}$ & 0.2 \\
& SIV-50 SD & & 0.1 & $1.7^{a * *}$ & \\
& & & 0.01 & $1.4^{a}$ & \\
[gamma]HCH & Rat/male & - & 1.0 & $0.8^{a}$ & \\
& SIV-50 SD & & 0.1 & $0.9^{a}$ & \\
& & & 0.01 & $1.3^{a}$ & \\
\hline
\end{tabular}

${ }^{*} 0.1 \geq P>0.05 ; * * P<0.05$ ( $t$-test)

${ }^{a}$ The related control group (Table VI).

fact that these authors measured DNA synthesis $35-36 \mathrm{~h}$ after TCDD administration, whereas we measured after $24 \mathrm{~h}$, which was found to coincide with the peak DNA synthesis in our system. Also, the dose used by these authors was 40 times larger than ours and it is possible that a potential toxicity interfered with the induction of DNA synthesis.

\section{Structural isomers}

It was investigated whether the test system was able to reflect the differences in carcinogenicity of structurally related compounds. Table IV summarizes the results obtained with the structural isomers [alpha]- and [gamma] $\mathrm{HCH}$. Whereas [gamma] $\mathrm{HCH}$ has no carcinogenic activity in rats (21a), the isomer [alpha]$\mathrm{HCH}$ is carcinogenic $(18 \mathrm{~b}, \mathrm{c})$. Only the carcinogenic [alpha] $\mathrm{HCH}$ isomer stimulated DNA synthesis with a DD of $0.2 \mathrm{mmol} / \mathrm{kg}$. The non-carcinogenic isomer [gamma] $\mathrm{HCH}$ did not have an effect on DNA synthesis.

The results obtained with a second pair of structurally related compounds are shown in Table V. DEHP is a liver carcinogen in rats (22c), while DEHA has no such effects in rats (22b). Both compounds were able to stimulate DNA synthesis with DD's of $0.5 \mathrm{mmol} / \mathrm{kg}$ for DEHP and $0.7 \mathrm{mmol} / \mathrm{kg}$ for DEHA. DEHA was the only compound tested so far where liver tumor induction and stimulation of DNA synthesis were not correlated.
Table $\mathbf{V}$. Correlation of carcinogenic potency with stimulation of liver DNA synthesis; structurally related compounds

\begin{tabular}{|c|c|c|c|c|c|}
\hline Compound & $\begin{array}{l}\text { Species/sex } \\
\text { strain }\end{array}$ & $\begin{array}{l}\text { Carcino- } \\
\text { genic } \\
\text { potency }\end{array}$ & $\begin{array}{l}\text { Dose } \\
(\mathrm{mmol} / \mathrm{kg})\end{array}$ & $\begin{array}{l}\text { Stimulation } \\
\text { factor }\end{array}$ & $\begin{array}{l}\text { Doubling } \\
\text { dose } \\
(\mathrm{mmol} / \mathrm{kg})\end{array}$ \\
\hline DEHA & $\begin{array}{l}\text { Rat/male } \\
\text { F-344 }\end{array}$ & - & 3.78 & $10.5^{e * *}$ & 0.7 \\
\hline DEHP & $\begin{array}{l}\text { Rat/male } \\
\text { F-344 }\end{array}$ & + & 1.73 & $7.8^{e * *}$ & 0.5 \\
\hline
\end{tabular}

${ }^{*} 0.1 \geq P>0.05 ;{ }^{* *} P<0.05$ ( $t$-test).

The related control group (Table VI).

\section{Control experiments}

Bioavailability of radiolabelled $T d R$. All results are based on measurements of the specific activity of liver DNA (d.p.m./mg) arising from the incorporation of methyl radiolabelled thymidine after oral gavage. Exhalation of ${ }^{14} \mathrm{CO}_{2}$ as a consequence of enzymatic thymidine degradation was routinely checked in order to assure that the bioavailability of the radiolabelled DNA precursor was uniform amongst the animals. On an average, $16 \pm 4 \%$ of the administered radioactivity in rats and $43 \pm 5 \%$ in mice was recovered as ${ }^{14} \mathrm{CO}_{2}$ within $3 \mathrm{~h}$.

Autoradiography. To prove that an increase in DNA radioactivity was correlated with an increase in dividing hepatocytes, a parallel experiment with an autoradiographic evaluation was conducted with $0.05 \mathrm{mmol} / \mathrm{kg}$ DDT. The fraction of cells in S-phase was $0.51 \%$, control liver showed $0.15 \%$. The SF by determination of the specific activity of the DNA and by autoradiographic analysis were therefore on a similar level.

Histology. Literature data show that regenerative DNA synthesis in rat liver after single administration of a necrogenic dose of $\mathrm{CCl}_{4}$ does not start until $30 \mathrm{~h}$ after the administration (24). A separation between adaptive (= promotive?) and regenerative liver DNA synthesis therefore seems possible. Nevertheless, in order to exclude the possibility that an increase in DNA radioactivity was only the result of regenerative processes after cell death induced by the test compounds, histological preparations of the livers were examined for necrotic regions after treatment with DDT, TAA, ALD, TCDD, DEHA and DEHP. An increase in necroses was never found.

Interindividual variability. In all experiments there was a large variability of the TdRII for equally treated animals. The standard deviation was on average about $50 \%$ of the mean value. The variability was not treatment-related, being also found in the controls. Table VI summarizes the mean values and standard deviations of the TdRIIs of all control groups. The means range from 2680 to 5540 in rats and from 850 to 1310 in mice. It was therefore necessary to relate the results of each experiment to its own control group. Unsuccessful attempts to reduce the variability will be discussed.

\section{Discussion}

It has been known for a long time that many xenobiotics induce liver growth. The topic has been comprehensively reviewed by Schulte-Hermann $(25,26)$. The role of liver growth in the process of carcinogenesis has been studied primarily on a mechanistic and cellular level and relatively little effort has been made to evaluate this response of the liver for toxicological purposes. In our assays, liver weights were not increased above control. This lack of an observable effect is most probably due to the short 


\begin{tabular}{|c|c|c|c|c|}
\hline $\begin{array}{l}\text { Group } \\
\text { (index) }\end{array}$ & $\begin{array}{l}\text { Mean value } \\
\text { of incorpora- } \\
\text { tion index }\end{array}$ & $\begin{array}{l}\text { Absolute } \\
\text { standard } \\
\text { deviation }\end{array}$ & $n$ & $\begin{array}{l}\text { Relative } \\
\text { standard } \\
\text { deviation (\%) }\end{array}$ \\
\hline \multicolumn{5}{|l|}{ A. Rats } \\
\hline$a$ & 2680 & 980 & 4 & 37 \\
\hline$b$ & 4370 & 2570 & 4 & 59 \\
\hline$c$ & 5540 & 4360 & 4 & 79 \\
\hline$d$ & 5080 & 3880 & 4 & 76 \\
\hline$e$ & 4600 & 1860 & 4 & 40 \\
\hline$f$ & 4270 & 1730 & 4 & 41 \\
\hline$g$ & 4280 & 3130 & 4 & 73 \\
\hline$h$ & 3460 & 430 & 4 & 12 \\
\hline \multicolumn{5}{|l|}{ B. Mice } \\
\hline$i$ & 850 & 580 & 3 & 67 \\
\hline$j$ & 1130 & 640 & 3 & 56 \\
\hline$k$ & 1310 & 260 & 4 & 20 \\
\hline
\end{tabular}

period of time between the administration of the test compound and the isolation of the liver DNA.

We have tried to characterize the liver's response in a quantitative way by comparing the doses required for various compounds to double the control level of DNA synthesis. Our results indicated in most cases not only a qualitative but also a quantitative correlation between the carcinogenic potency and the DNA synthesis stimulating potency (expressed as the DD) of carcinogens which do not act by DNA binding. Compounds with a high carcinogenic potency were active at lower dose levels to stimulate DNA synthesis than compounds with a lower potency. DNA-binding carcinogens did not stimulate DNA synthesis at all. Therefore the stimulation test could represent a useful tool for detecting a number of carcinogens which are missed by the routine genotoxicity test systems.

Furthermore, we checked whether compounds that induce liver tumors only in one rodent species, or only in one sex would stimulate DNA synthesis in the susceptible but not in the resistant case. For the compounds investigated in this study, it was possible to pinpoint mouse- or rat-specific carcinogens and sex-specific carcinogens. A difference in carcinogenicity of structurally-related compounds was reflected by the assay with the $\mathrm{HCH}$ isomers but not with the plasticizers DEHP and DEHA. Further work is necessary to elucidate this 'false positive' situation.

\section{Attempts to reduce the interindividual variability}

A large interindividual variability sometimes unacceptably reduced the level of significance of an effect. Various means were tested to reduce this drawback:(1) $\left[{ }^{14} \mathrm{C}\right]$ methanol was used instead of $\left[{ }^{14} \mathrm{C}\right]$ thymidine to label all four nucleotides via the carbon-1 pool; (2) only brothers were taken in a treatment group, to have genetically similar animals; (3) food was available for $15 \mathrm{~h}$ instead of $5 \mathrm{~h}$ in order to reduce the stress of hunger; (4) 'internal standardization': at day 0 at 8 a.m., the animals were administered $\left[{ }^{3} \mathrm{H}\right] \mathrm{TdR}$, to determine the level of DNA synthesis before treatment with the test compound. Twenty-four hours later the animals were given the test compound. After additional $24 \mathrm{~h}$, they received $\left[{ }^{14} \mathrm{C}\right] \mathrm{TdR}$, to determine the level of DNA synthesis after the treatment with the test compound. On the basis of the ${ }^{3} \mathrm{H}$ - and the ${ }^{14} \mathrm{C}$-counts in each liver DNA every animal served as its own control. Unfortunately, none of these procedures resulted in a reduction of the variability (data not shown).
Combination with short-term tests for genotoxicity and future developments

The assay proposed here seems to be useful to recognize some of those carcinogens which are notoriously missed by tests for genotoxicity. The concept of the doubling dose (i.e. the single dose of a compound required to double the control level of DNA synthesis) might even allow a quantitative evaluation. Parodi and co-workers have shown that a combination of two short-term tests leads to an improvement of the predictivity if both tests can be evaluated quantitatively and if both tests correlate to some extent with carcinogenic potency. The improvement will be maximal if the two tests recognize different classes of carcinogens, i.e. do not correlate with each other (27). A preliminary analysis of the present data showed that a combination of the DD with a quantitative short-term test for genotoxicity, for instance with a test measuring covalent DNA binding in vivo (1) indeed markedly improved the prediction of the potency of a carcinogen on the basis of a combination of two short-term tests (28).

The results show that a single administration of the test compound is sufficient to induce an observable effect and to provide a surprisingly good correlation with carcinogenic potency. It might be expected that a repeated application would reflect the real situation even better. It is also imaginable that this could reduce the interindividual variability, because fluctuations from day to day would be averaged out. On the other hand, the costs for performing the test would be greater than with a single application.

With the compounds investigated so far, only one false positive and no false negative result was found. This is an astonishingly good result. It is probable, however, that false negative results sometimes will also be found, because no short-term test can be expected to reflect all aspects and stages of carcinogenesis by chemicals. It could, for instance, be imagined that a compound leads to an increased formation of peroxides and oxygen radicals able to damage DNA. This indirect genotoxicity would go unobserved in a DNA binding study and possibly also in a test on DNA synthesis, although it was recently reported that hydroperoxides of fatty acids stimulated DNA synthesis in rat colon (29). It will then be necessary to search for the biological activity responsible in that specific situation for the tumors induced, and to try to develop a corresponding short-term test. This would finally allow the replacement of the long-term bioassay for carcinogenicity by a battery of test systems with complementary scope. The mechanistic information available from such a combination of assays would also be of value for extrapolations to man.

\section{Acknowledgements}

This work was supported by the Krebsliga des Kantons Zürich.

\section{References}

1. Lutz,W.K. (1979) In vivo covalent binding of organic chemucals to DNA as a quantitative indicator in the process of chemical carcinogenesis. Mutat. Res. 65, $289-356$.

2. Williams,G.M. (1981) The detection of genotoxic chemicals in the hepatocyte primary culture/DNA repair test. Gann Monogr. Cancer Res., 27, 45-55.

3. McCann,J., Choi,E., Yamasaki,E. and Ames,B.N. (1975) Detection of carcinogens as mutagens in the Salmonella/microsome test: assay of 300 chemicals.Proc. Natl. Acad. Sci. USA, 72, 5135-5139.

4. Ashby,J., de Serres,F.J., Draper,M., Ishidate,M., Margolin.B.H., Matter,B.E. and Shelby,M.D. (eds) (1985) Evaluation of Short-rerm Tests for Carcinogens. Elsevier Science Publishers, Amsterdam. 
5. Armuth,V. and Berenblum,I. (1972) Systemic promoting action of phorbol in liver and lung carcinogenesis in AKR mice. Cancer Res., 32, 2259-2262.

6. Peraino,C., Fry,R.J.M., Staffeldt,E. and Christopher,J.P. (1975) Comparative enhancing effects of phenobarbital, amobarbital, diphenylhydantoin, and dichlorodiphenyltrichloroethane on 2-acetylaminofluorene-induced hepatic tumorigenesis in the rat. Cancer Res., 35, 2884-2890.

7. Goldsworthy,T.L. and Pitot,H.C. (1985) An approach to the development of a short-term whole animal bioassay to distinguish initiating agents (incomplete carcinogens), promoting agents, complete carcinogens, and noncarcinogens in rat liver. J. Toxicol. Environ. Health, 16, 389-402.

8. Abanobi,S.E., Lombard, B. and Shinozuka,H. (1982) Stimulation of DNA synthesis and cell proliferation in the liver of rats fed a choline-devold diet and their suppression by phenobarbital. Cancer Res., 42, 412-415.

9. Colbum,N.C., Wendel,E.J. and Abruzzo,G. (1981) Dissociation of mitogenesis and late-stage promotion of tumor cell phenotype by phorbol esters: mitogen-resistant variants are sensitive to promotion. Proc. Natl. Acad. Sci. $U S A, 78,6912-6916$

10. Cayama,E., Tsuda,H., Sarma,D.S.R. and Farber,E. (1978) Initiation of chemical carcinogenesis requires cell proliferation. Nature, 275, 60-62.

11. Columbano,A., Rajalakshmi,S. and Sarma,D.S.R. (1981) Requirement of cell proliferation for the intiation of liver carcinogenesis as assayed by three different procedures. Cancer Res., 41, 2079-2083.

12. Craddock,V.M. (1976) Cell proliferation and experimental liver cancer. In Cameron,H.M., Linsel,D.A. and Warwick,G.P. (eds), Liver Cell Cancer. Elsevier/North Holland Biomedical Press, Amsterdam, pp. 153-201.

13. Kinzel,V., Fürstenberger,G., Loehrke,H. and Marks,F. (1986) Three-stage tumorigenesis in mouse skin: DNA synthesis as a prerequisite for the conversion stage induced by TPA prior to initiation. Carcinogenesis, 7, 779-782.

14. Scribner,J.D. and Süss, R. (1978) Tumor initiation and promotion. Int. Rev. Exp. Pathol., 18, 137-198.

15. Schulte-Hermann, R. and Landgraf,H. (1974) Circadian rhythm of cell proliferation in rat liver: synchronisation by feeding habits. Z. Naturforsch., 29c, $421-424$.

16. Viviani,A. and Lutz,W.K. (1978) Modulation of the binding of the carcinogen benzo[a]pyrene to rat liver DNA in vivo by selective induction of microsomal and nuclear aryl hydrocarbon hydroxylase activity. Cancer Res., 38, $4640-4644$.

17. Gold,L.S., Sawyer,C.B., Magaw,R., Backman,G.M., de Veciana,M., Levinson,R., Hooper,N.K., Havender,W.R., Bernstein,L., Peto,R., Pike,M.C. and Ames,B.N. (1984) A carcinogenic potency database of the standardized result of animal bioassays. Environ. Hlth Perspect., 58, 9-319.

18. IARC Monographs on the Evaluation of the Carcinogenic Risk of Chemicals to Humans. International Agency for Research on Cancer, Lyon. a: Vol. 1, 1972; b: Vol. 5, 1974; c: Vol. 20, 1979; d: Vol. 24, 1980; e: Vol. 29, 1982.

19. Rossi,L., Ravera,M., Repetti,G. and Santi,L. (1977) Long-term adminstration of DDT or phenobarbital-Na in Wistar rats. Int. J. Cancer, 19, 179-185.

20. Dasgupta,A., Chatterjee,R. and Chowdhury,J.R. (1981) Thioacetamideinduced hepatocarcinoma in rat. Oncology, 38, 249-253

21. National Cancer Institute (NCI), Carcinogenesis, Technical Reporn Series. Bioassays for Possible Carcinogenicity. US Department of Health, Education, and Welfare, Public Health Service, National Institutes of Health. a: Vol. 14, 1977; b: Vol. 21, 1978

22. National Toxicology Program (NTP), Carcinogenesis, Technical Report Series. Carcinogenesis Bioassays. US Department of Health and Human Services, Public Health Service, National Institutes of Health. a: Vol. 209, 1982; b: Vol. 212, 1982; c: Vol. 217, 1982.

23. Christian,B.J. and Peterson,R.E. (1983) Effects of 2,3,7,8-tetrachlorodibenzo-p-dioxin on $\left[{ }^{3} \mathrm{H}\right]$ thymidine incorporation into rat liver deoxyribonucleic acid. Toxicology, 28, 133-146.

24. Doerfler,J. (1982) Einfluss von Hepatomitogenen und Emährung auf die DNS-Synthese und Monooxygenaseaktivität in der Rattenleber nach Tetrachlorkohlenstoffvergiftung. Inaugural-Dissertation, Instiut für Toxikologie und Pharmakologie der Universität Marburg/Lahn.

25. Schulte-Hermann, R. (1974) Induction of liver growth by xenobiotic compounds and other stimuli. CRC Crit. Rev. Toxicol., 3, 97-158.

26. Schulte-Hermann, R. (1985) Tumor promotion in the liver. Archs. Toxicol., 57, 147-158.

27. Parodi,S., Taningher,M., Boero,P. and Santi,L. (1982) Quantitative correlations amongst alkaline DNA fragmentation, DNA covalent binding, mutagenicity in the Ames test and carcinogenicity for 21 compounds. Mutat. Res., 93, 1-24.

28. Lutz,W.K., Büsser,M.-T. and Sagelsdorff,P. (1984) Potency of carcinogens derived from covalent DNA binding and stimulation of DNA synthesis in rat liver. Toxicol. Pathol., 12, 106-111.

29. Bull,A.W., Nigro,N.D., Golembieski,W.A., Crissman,J.D. and Mamett,L.J. (1984) In vivo stimulation of DNA synthesis and induction of ornithine decar- boxylase in rat colon by fatty acid hydroperoxides, autoxidation products of unsaturated fatty acids. Cancer Res., 44, 4924-4928.

Received on March 9, 1987; accepted on July 10, 1987 